\title{
VARIETAL SCREENING OF OKRA ( Abelmoschus esculentusL. MOENCH ) AGAINST OKRA YELLOW VEIN MOSAIC VIRUS UNDER DIFFERENT MANAGEMENT PRACTICES AT PAKLIHAWA, RUPANDEHI, NEPAL
}

\author{
R. Poudel, A. Pandey, K. Poudel, A. Chaudhary, N. Ghimire and S. Ghimire \\ Paklihawa Campus, Institute of Agriculture and Animal Science \\ *rajan@iaas.edu.np
}

\begin{abstract}
The experiment was conducted in the Horticulture farm of Institute of Agriculture and Animal Science, Paklihawa, Rupandehi, Nepal from March, 2017 to June, 2017 to screen the varieties of okra against Okra yellow vein mosaic virus under different management practices. The experiment was laid out in two factorial Split plot design and replicated three times. Five varieties of okra viz. Parvati, Arka Anamika, NOH-15, Super Green and Julie were used and five treatments viz. Jholmol (1:5), Azadiracthin $(5 \mathrm{ml} / \mathrm{L})$, Imidacloprid $(2 \mathrm{ml} / \mathrm{L})$, cow milk $(100 \mathrm{ml} / \mathrm{L})$ and control (distilled water) were used as foliar spray on plants. The chlorophyll content of the leaves was higher in Julie followed by Arka Anamika. The white fly count was found to be reduced after the application of treatments in the succeeding date in almost all varieties. The efficiency of the management practices was found to be significant with Super Green and Julie varieties with least Percent Disease Incidence(PDI) value and in par with each other. Imidacloprid and Azadiractin had the leastPDI value and the combination of Super Green variety with Imidacloprid, Super Green with Jholmol, Super Green with cow milk, Julie with Imidacloprid, NOH-15 with Imidacloprid were found resistant. Similarly, the highest yield was obtained in Julie with Imidaclropid combination. However, due to the maximum waiting period of this chemical as well as its negative impact on human and plant health, Julie with Azadirachtin combination can be suggested to farmers to have eco-friendly management of Okra yellow vein mosaic virus
\end{abstract}

Keywords: okra, OYVMV, whitefly, treatment, disease control

\section{INTRODUCTION}

Okra (Abelmoschus esculentus L. Moench) also known as Ladies Fingers is a member of Malvaceae family. Locally it is known as 'Bhindi' or 'Chiple bhindi'. It is an important vegetable crop in the tropical and sub tropical regions in the world (Osekita, 2009). It probably originated in either tropical Africa or tropical Asia, and is now widely grown throughout the tropics (Ali et al., 2012). The crop is well distributed throughout the Indian subcontinent and East Asia (Rashid, 1999).

Okra is a multipurpose crop. The tender okra pods are consumed fresh as well as canned and dried. Okra seeds are roasted, grounded and used as substitute of coffee in Turkey. It is a nutritious and delicious vegetable, fairly rich in vitamins and minerals(Khushk, Usman, \& Memon, 2003). The edible portion of pod (100g) has moderate levels of vitamin A (375 IU), vitamin C (21.1 mg), calcium (81mg), phosphorus (63mg) and potassium (303mg). (USDA National Nutrient Database) The content of thiamine $(0.07 \mathrm{mg})$, riboflavin $(0.08 \mathrm{mg})$ and niacin $(0.08 \mathrm{mg})$ per $100 \mathrm{gm}$ edible portion of pod is higher than that of many vegetables (Rashid, 1999).

Okra production in tropical regions is constrained by several abiotic and biotic factors.Abiotic factors include the temperature, relative humidity, rainfall and soil. Biotic factors include: pathogens (bacteria, fungi, virus, mycoplasm and nematodes), insect-pests and weeds. Yield losses of the vegetables due to biotic factors are quite substantial, about $20 \%$, which may increase up to $90 \%$. Among the factors limiting okra production, yellow vein mosaic virus, a member of gemini viridae 
family, semi-persistently transmitted by the vector whitefly, is the most serious disease (Sastry \& Singh, 1975). The common host range of okra yellow vein mosaic virus (OYVMV) is restricted to Malvaceae plants through the vector could be able to transmit virus in six different plant species. These include Hibiscus, Cotton, Cocao, Kolanut, Bottle tree, Bombax cotton (Capoor \& Verma, 1950).

The insect vector, White fly (Bemesia tabaci) has been reported in more than 600 host plants, most of which are of immense importance to worldwide agriculture production (Oliveria, Henneberry, \& Anderson, 2001). Whitefly remains active on many hosts throughout the year. Of these, brinjal, chillies, cucurbits, cotton, menthe, okra, potato, rapeseed, sunflower, soyabean and tomato are important hosts for this pest (Sharma, Gupta, Jindal, \& Dilawari, 2008).

The study of management of OYVMV through pesticide/biopesticide and suitable cultivars was conducted and found that Imidacloprid significantly reduced the whitefly population. Neem extract and bio-control (EM) were also found to be effective against the whitefly compared to distilled water and untreated control (Ali, Khan, Habib, Rasheed, \& Iftikhar, 2005).

The study on management of OYVMV through Mycotol, Tracer and Imidacloprid was performed and found that response of various varieties varies greatly regarding the level of resistance and susceptibility (Ali, Khan, Rashid, \& Sajid, 2012). Neem extract at 5\% concentration applied at 15 days interval starting from two weeks after germination was found effective in reducing OYVMV disease incidence and whitefly counts under field condition (Chaudhary, Khan, \& Bilal, 2016).

\section{MATERIALS AND METHODS}

The experiment was conducted at Institute of Agriculture and Animal Science (IAAS), Paklihawa, Rupandehi, Nepal during March to July 2017 in Split Plot Design with 3 replications. The varieties of okra were Parvati, Arka Anamika, NOH-15, Super Green and Julie were used and the treatments were Jholmol, Azadirachtin, Imidacloprid, Cow milk and Control. There were 5 main plots in each replication with 5 split plots. Altogether there were 25 split plots in each replication with a total of 75 split plots. The total area of the plot was $22.5 \mathrm{~m} \times 7.55 \mathrm{~m}\left(170.25 \mathrm{~m}^{2}\right)$. Similarly, area of each main plot was $7.35 \mathrm{X}$ 1.35 with $1.35 \times 1.35 \mathrm{~m}^{2}$ of area of split plot within the main plot. Spacing between the replication were $25 \mathrm{~cm}$, main plots were $20 \mathrm{~cm}$, split plots were $15 \mathrm{~cm}$. Three rows of plants were maintained with plant to plant spacing row to row spacing of $45 \mathrm{~cm}$ and $45 \mathrm{~cm}$ respectively.

Required amount of seeds of each varieties were calculated which were later soaked separately in a plastic pot for 12 hours. It was, then, wrapped in a thin cloth for 6 hours to facilitate priming and sprouting of seeds. Seeds were sown the next day. Two yellow sticky traps were installed in the field 25 days after sowing(DAS) to monitor white flies. After the first disease appearance in okra plants,Jholmol (1:5), Azadirachtin (5ml/L), Imidacloprid (2mal/L), Cow milk $(100 \mathrm{ml} / \mathrm{L})$ and Control (distilled water) were applied as foliar spray. Total 3 sprays were made at regular interval of 15 days.

To describe disease reaction against Yellow Vein Mosaic Virus, scale given by Banerjee and Kalloo, 1982 was used. The scale is shown in table 1.

Table 1: Scale of classifying disease reaction against Yellow Vein Mosaic Virus (Banerjee and Kalloo, 1982)

\begin{tabular}{lllll}
\hline Appearance of YVMV symptoms & Symptoms & Response value & CI & Reaction \\
\hline Absent & 0 & 0 & $0-4$ & HR \\
$<25 \%$ leaves & 1 & 0.25 & $5-9$ & R \\
$25-50 \%$ leaves & 2 & 0.5 & $10-19$ & MR \\
$50-75 \%$ leaves & 3 & 0.75 & $20-39$ & MS \\
$75-90 \%$ leaves & 4 & 1 & $40-69$ & S
\end{tabular}




\begin{tabular}{llll}
$>90 \%$ leaves & 5 & - & $70-100$ \\
\hline
\end{tabular}

To describe the disease intensity in the plants and severity in leaves, following calculations were done based on the formula given by Karry and Acharyya, 2012.

\section{Percentage Disease Incidence (PDI):}

$$
\% \text { Disease Incidence }=\frac{\text { No of infected plants X } 100}{\text { Total no. of plants }}
$$

\section{Coefficient of Infection (CI):}

\section{$\mathrm{CI}=\mathrm{PDI} X \mathrm{RV}$}

Where, $\mathrm{RV}=$ Response value assigned based on severity of infected leaves.

CI value helps to establish the resistance trait of the varieties.

Four sample plants representative of each plot were selected and different parameters were assessed on the same plant. The parameters were number of leaves/ plant, number of infected leaves/ plant, white fly count and total yield. The obtained data were analyzed by using R-stat software package. Daily data on maximum temperature, minimum temperature and total rainfall were taken from National Wheat Research Program (NWRP) Bhairahawa, Rupandehi, Nepal that lies near the experimental field. According to the weekly weather data of the experimental field during experimental period (Mar.2017 - Jun. 2017) at IAAS Paklihawa, Nepal; temperature was favorable for both okra yellow vein mosaic virus and white fly.

\section{RESULT AND DISCUSSION}

\section{White fly counts}

The maximum whitefly count was found on Parvati variety before the application of treatment and the least on Arka Anamika. Similarly at the end of application of third treatment, Super Green reduced the whitefly number to a greater degree compared to others while the greater infestation was found on $\mathrm{NOH}-15$. Ali et al., (2012) also found the decreasing count of whitefly after the application of treatment.

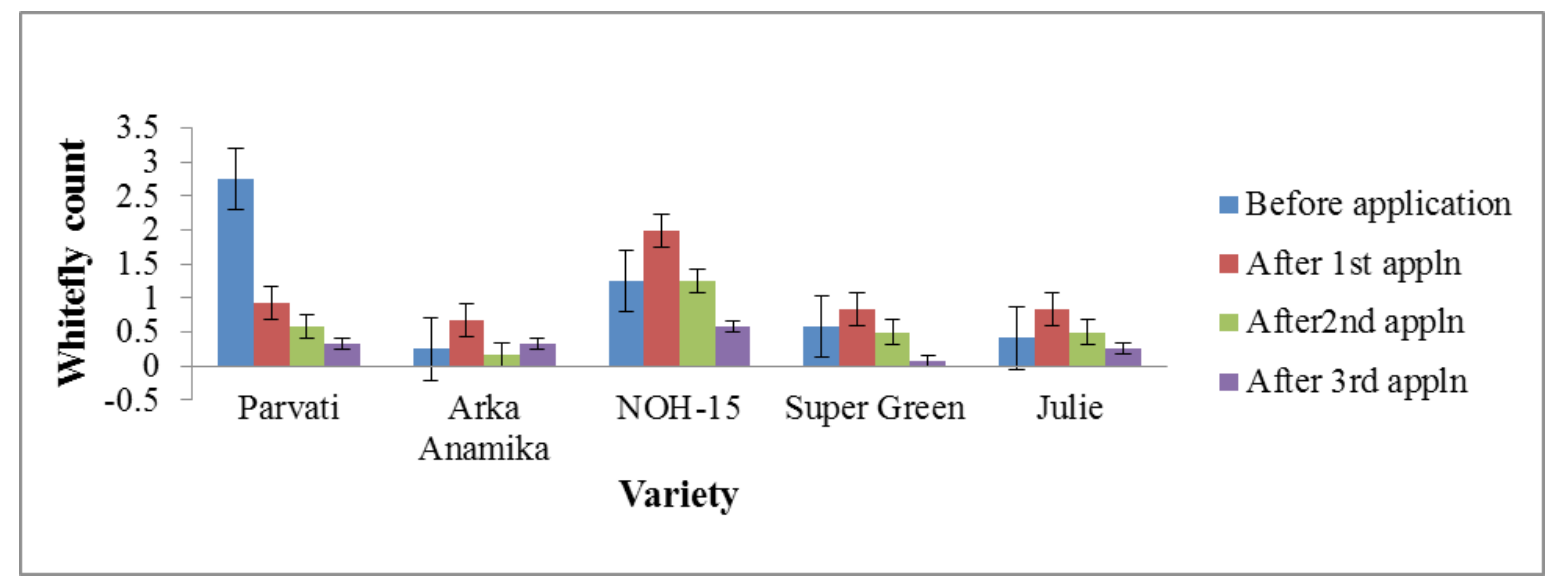

Figure 1: Variation on whitefly count in different varieties after different application of treatment at IAAS, Paklihawa, 2017 


\section{Varietal response against PDI under different management practices:}

PDI value was measure at the first disease scoring; 5 days after the treatment and the last scoring were done; 5 days after final treatment. The result shows the performance of different management options for the different varieties.

\section{Jholmol}

NOH-15 and Parvati were found with high PDI value compared to other variety (54.45) and the least PDI value was found in Julie at the end of scoring when the varieties were treated with Jholmal. The bar graph below shows that PDI value increased in the second scoring in all varieties except for Julie. It may be due to the occurrence of rainfall one day before the scoring, that might have washed away the residues of treatment attached on the leaves. Similarly, this decreased on the third scoring done 5 days after the next application of treatment.

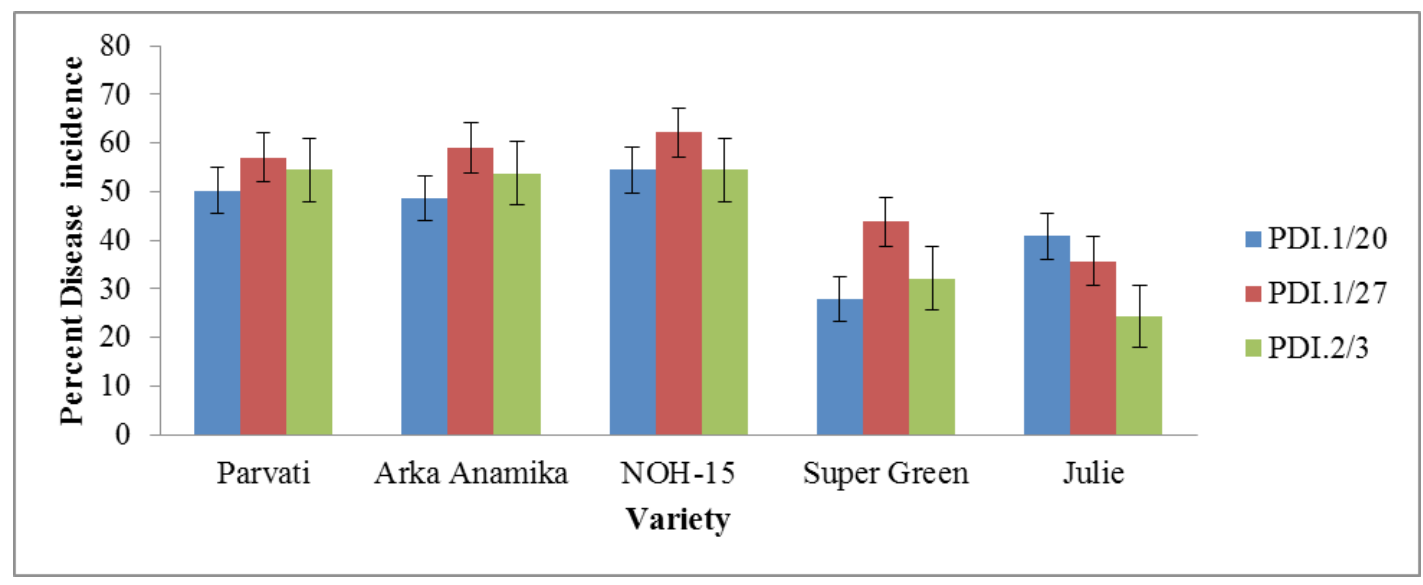

Figure 2: Varietal response against PDI under Jholmol treatment on different dates

\section{Azadiractin}

Highest PDI value was found on Parvati variety (61.57) followed by Arka anamika (50.293) and the least PDI value was found in NOH- 15 (38.7) when treated with Azadirachtin. PDI was found to be highest in the second scoring in all varieties except for Parvati. This also might be due to the rainfall one day prior the scoring and these started decreasing after the application of another treatment.(Ali S. , Khan, Habib, Rasheed, \& Iftikhar, 2005)also found that Neem extract to be effective against Bemesia tabaci.

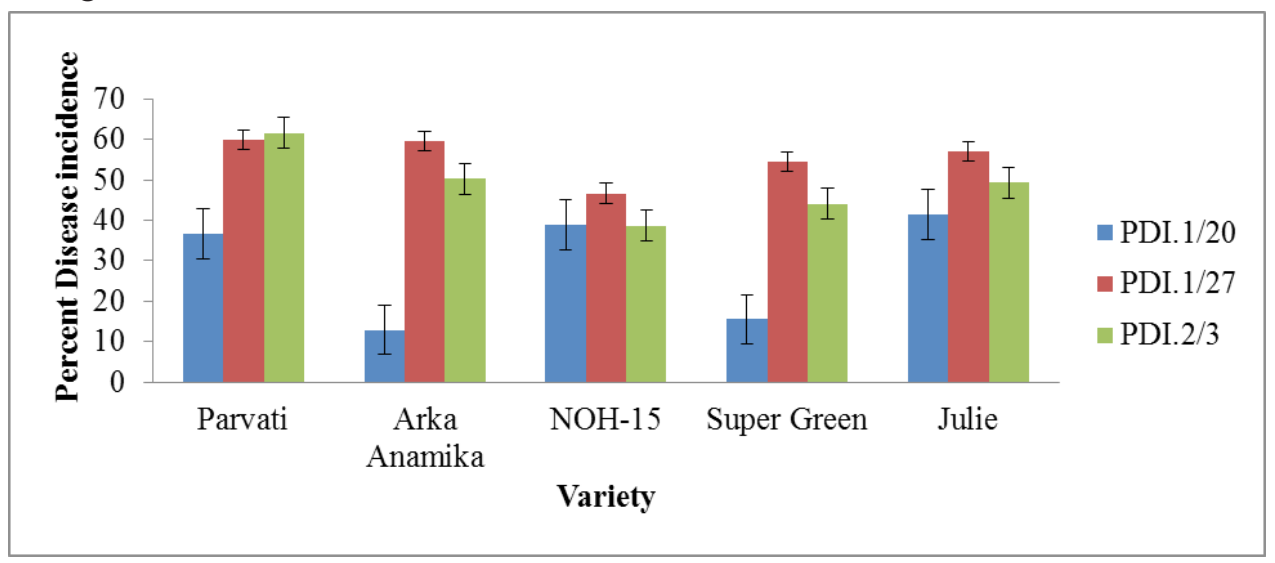

Figure 3: Varietal response against PDI under Azadiractin treatment on different dates at Paklihawa, 2017 


\section{Imidacloprid}

Highest PDI value was found on Parvati variety (45.697) followed by Arka anamika (40.187) and the least PDI value was found in Julie (25.925) when treated with Imidacloprid.Ali et al., (2012) found Imidacloprid to be effective in decreasing PDI value compared to others.

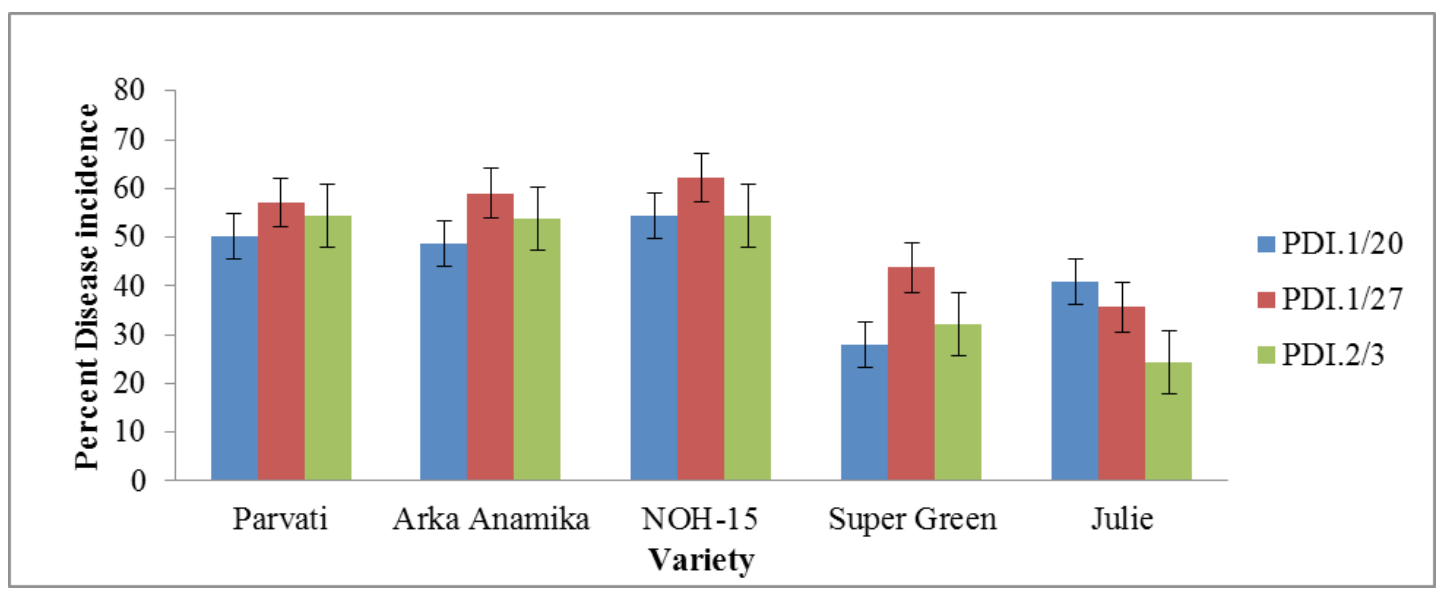

Figure 4: Varietal response against PDI under Imidacloprid on different dates at IAAS, Paklihawa, 2017

\section{Raw Cow's milk}

Highest PDI value was found on Parvati variety ( 61.99) followed by NOH - 15 ( 57.47 ) and the least PDI value was found in Super Green ( 34.72 ) when treated with raw cow's milk on the third disease scoring.

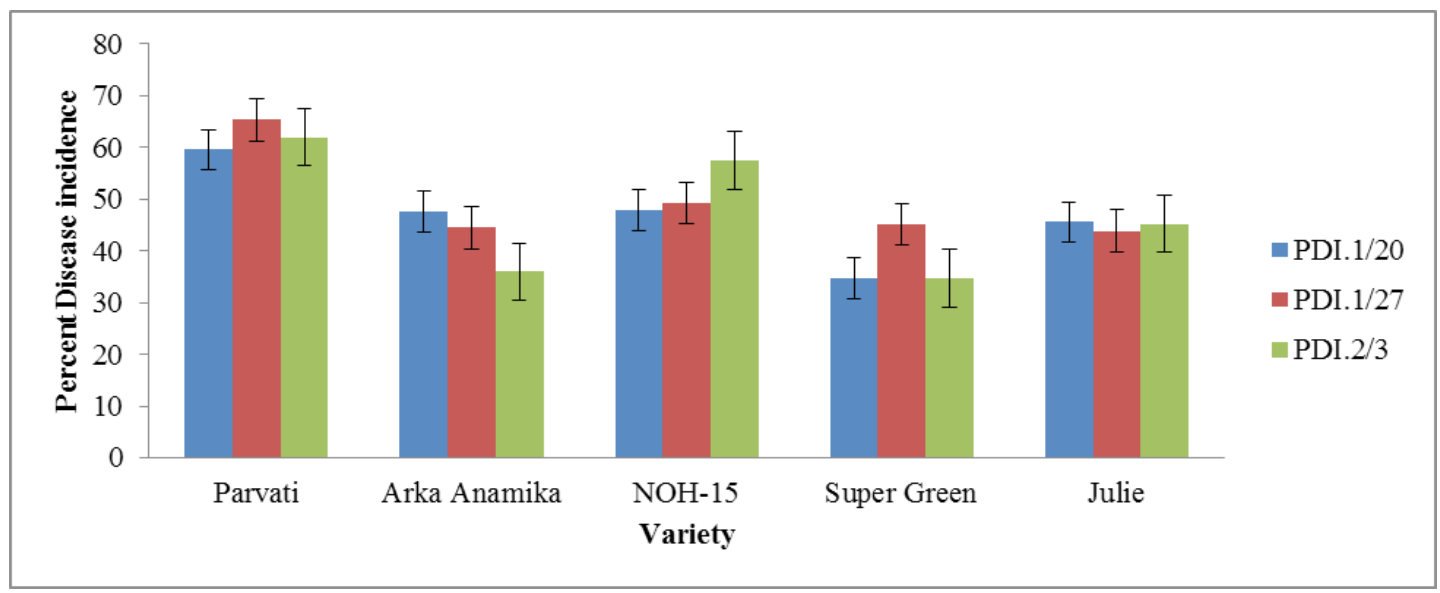

Figure 5: Varietal response against PDI under Raw cow's milk on different dates at IAAS, Paklihawa, 2017

\section{Control}

Highest PDI value was found on $\mathrm{NOH}$ - 15 ( 84.33 ) followed by Parvati ( 80.66 ) and the least PDI value was found in Julie ( 73.993 ) under controlled condition on the third disease scoring. 


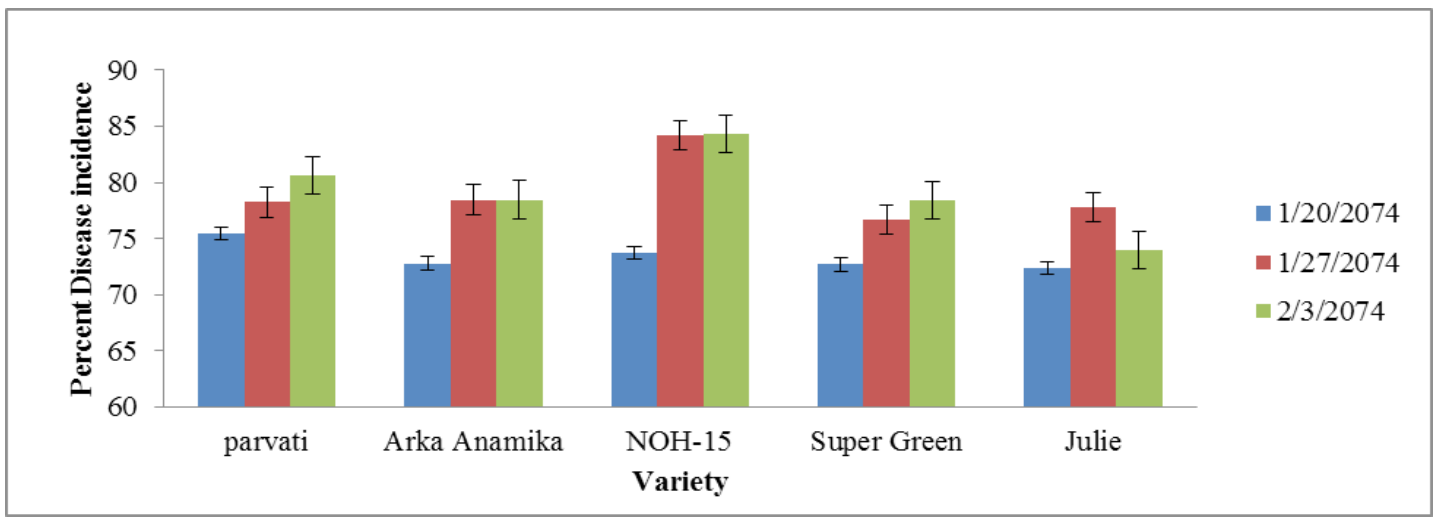

Fig 6: Varietal response against PDI under controlled condition on different dates at IAAS, Paklihawa, 2017

\section{Correlation and regression analysis}

\section{a) \% leaves infected and PDI}

The experimental research carried out found that \% leaves infected and PDI were positively correlated and were linear. The linear regression equation $y=1.816 \mathrm{x}+36.73$ showed that if there is per unit increase in \% leaves infected, PDI increased by 1.816 units. According to coefficient of regression, $30.9 \%$ variation in $\mathrm{PDI}$ is due to \% leaves infected.

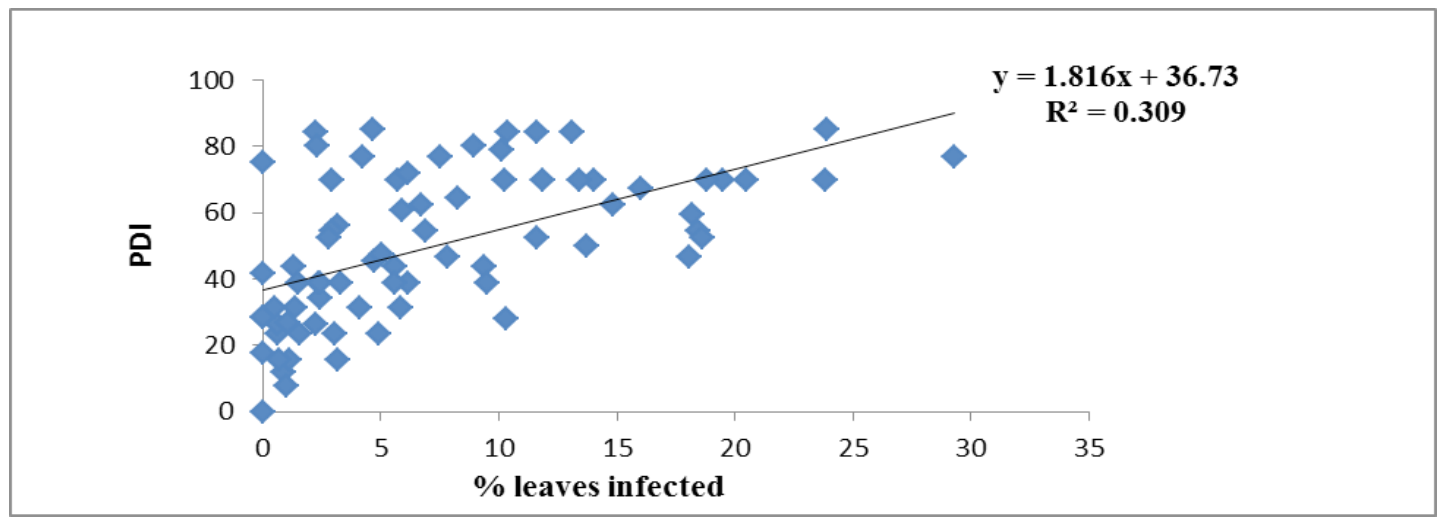

Fig7: Relationship between \% leaves infected and PDI

\section{b) Coefficient of Infection and Average Yield:}

Coefficient of infection and average yield were negatively correlated. From the experimental research, we found out per unit increase in coefficient of infection reduced the average yield by 0.791 units. Regression value shows that $16.5 \%$ decrease in yield was due to coefficient of infection and remaining were due to other factors. 


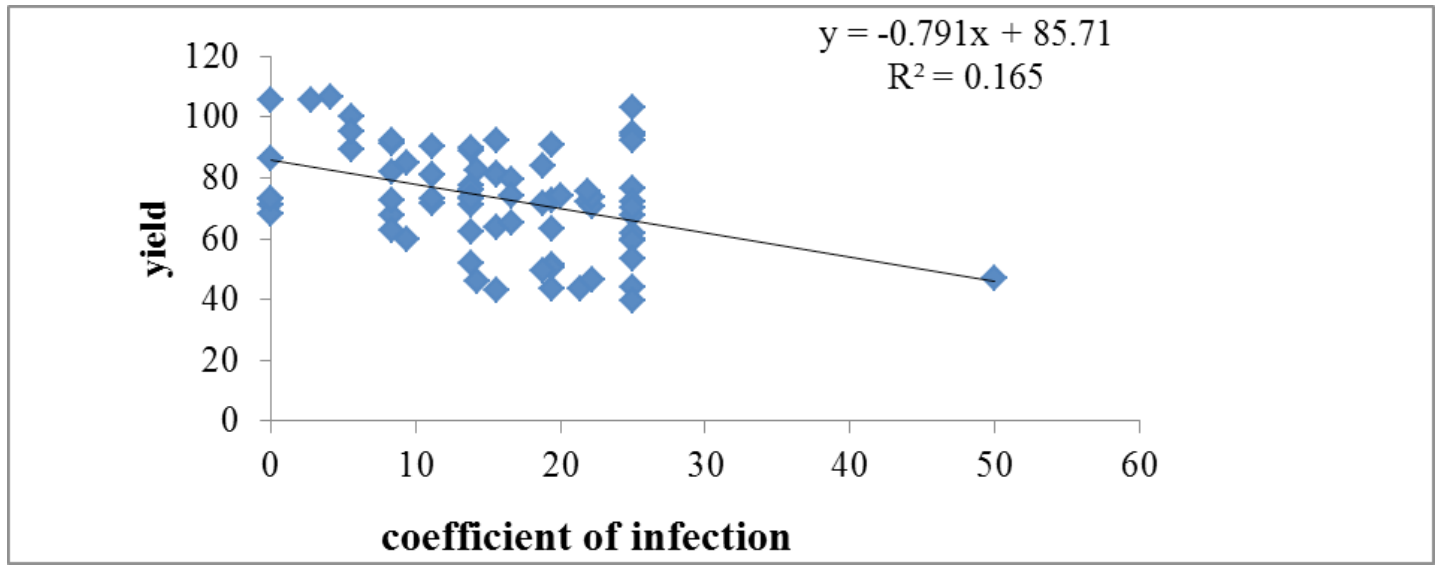

Figure 8: Relation between Coefficient of Infection and Average yield (gm)

Measurement of PDI of different variety on different dates

Table 2: Mean PDI value of different varieties on different dates at Paklihawa, 2017

\begin{tabular}{lll}
\hline Varietal treatment & Mean PDI (O74.1.20) & Mean PDI (074.1.27) \\
\hline Parvati & $57.56^{\mathrm{a}}$ & $64.93^{\mathrm{a}}$ \\
NOH 15 & $52.14^{\mathrm{ab}}$ & $53.66^{\mathrm{ab}}$ \\
Julie & $47.30^{\mathrm{abc}}$ & $49.31^{\mathrm{b}}$ \\
Arka Anamika & $42.42^{\mathrm{bc}}$ & $56.91^{\mathrm{ab}}$ \\
Super Green & $36.24^{\mathrm{c}}$ & $50.40^{\mathrm{ab}}$ \\
\hline PR $(>\mathrm{F})$ & $0.0179^{*}$ & 0.159 \\
Mean & 47.13 & 55.04 \\
\hline
\end{tabular}

Parvati had the maximum PDI (57.5694) at the first scoring followed by NOH $-15(52.14120)$ while the lowest value was found on Super Green (36.24547) which is significantly different than other variety. Similarly on the second scoring Julie had least PDI value (49.3120) but the highest PDI value was of Parvati (64.9328).

Table 3: Total PDI value of different management practices recorded on different dates at Paklihawa, 2017

\begin{tabular}{lll}
\hline Varietal treatment & Mean PDI (O74.1.20) & Mean PDI (074.1.27) \\
\hline Control & $73.38^{\mathrm{a}}$ & $79.07^{\mathrm{a}}$ \\
Cow milk & $47.09^{\mathrm{b}}$ & $53.65^{\mathrm{b}}$ \\
Jholmal & $44.72^{\mathrm{b}}$ & $51.52^{\mathrm{b}}$ \\
Imidaclropid & $37.49^{\mathrm{bc}}$ & $36.12^{\mathrm{c}}$ \\
Azadirachtin & $32.99^{\mathrm{c}}$ & $54.83^{\mathrm{b}}$ \\
\hline PR $(>\mathrm{F})$ & $0.000^{* * *}$ & $0.000^{* * *}$ \\
Mean & 47.13 & 55.04 \\
\hline
\end{tabular}


The above table shows that Azadirachtin to be highy efficient than others due to its low PDI value (32.99) and that of Control to be less (73.39) in the first disease scoring but the trend didi not continued the same on second scoring. Imidacloprid was found with low PDI (36.13) and Control was found with high PDI (79.07). On both the date, the treatment were found to be highly significant as shown by $\operatorname{Pr}(>\mathrm{F})$ that is $4.78 \mathrm{e}-08 * * *$ on the first scoring and $2.32 \mathrm{e}-08 * * *$ on the second scoring.

Moreover, it was observed that Parvati under the controlled condition has high PDI value (75.436) compared to others followed by NOH-15 under the controlled condition (73.715). Also, other varieties under the controlled condition follow after this treatment. Similarly, the lowest PDI value was observed in Super green Azadirachtin treatment under the first scoring. Later, Arka Anamika under controlled condition has highest PDI value (78.45) followed by Parvati under controlled condition (78.226) while Super Green under Imidacloprid treatment has lowest PDI value (24.628) followed by NOH-15 under Imidacloprid (24.63).

Table 4: Total yield of different varieties at IAAS, Paklihawa, 2017

\begin{tabular}{ll}
\hline Varietal treatment & Mean yield(gm) \\
\hline Parvati & $546.70^{\mathrm{a}}$ \\
NOH 15 & $461.19^{\mathrm{ab}}$ \\
Julie & $402.63^{\mathrm{ab}}$ \\
Arka Anamika & $401.20^{\mathrm{ab}}$ \\
Super Green & $218.41^{\mathrm{b}}$ \\
\hline PR $(>\mathrm{F})$ & 0.321 \\
Mean & 406.03 \\
\hline
\end{tabular}

Above table shows that Julie variety had the highest yield than other variety (546.70) followed by NOH-15(461.19) while the lowest yield was found on Super Green. The grand mean was found to be 406.03. Also, the mean yield was not significant at the 0.05 level of significance.

Table 5: Total yield under different management options at IAAS, Paklihawa, 2017

\begin{tabular}{ll}
\hline Varietal treatment & Mean yield $(\mathrm{gm})$ \\
\hline Control & $893.91^{\mathrm{a}}$ \\
Cow milk & $307.59^{\mathrm{b}}$ \\
Jholmal & $290.49^{\mathrm{b}}$ \\
Imidaclropid & $277.70^{\mathrm{b}}$ \\
Azadirachtin & $260.43^{\mathrm{b}}$ \\
\hline PR $(>\mathrm{F})$ & $0.000^{* * *}$ \\
Mean & 406.03 \\
\hline
\end{tabular}

Above table shows that Imidacloprid gave the highest yield (893.918) followed by Jholmal (307.59) and the lowest yield was found on Control plot (260.43). Grand mean was observed to be 406.03. Similarly, yield was found to be highly significant under the 0.05 level of significance.

Moreover, Julie under Imidacloprid treatment has highest yield (1152.08), significantly different than other treatment followed by Parvati under Imidacloprid (957.65). Lowest yield has been recorded in Super Green under control treatment (89.85) followed by Super Green under Jholmal (93.40). 
Table 6: Response of different Variety and Management Interaction in IAAS, Paklihawa,2017

\begin{tabular}{lllll}
\hline S.NO. & Variety & Management & Average CI & Response \\
\hline $\mathbf{1}$ & Parvati & Jholmal & 13.82753 & MR \\
$\mathbf{2}$ & Parvati & Azadirachtin & 15.25469 & MR \\
$\mathbf{3}$ & Parvati & Imidacloprid & 12.89342 & MR \\
$\mathbf{4}$ & Parvati & Cow's milk & 21.90194 & MS \\
$\mathbf{5}$ & Parvati & Control & 19.96222 & MS \\
$\mathbf{6}$ & Arka Anamika & Jholmal & 13.88139 & MR \\
$\mathbf{7}$ & Arka Anamika & Azadirachtin & 10.67306 & MR \\
$\mathbf{8}$ & Arka Anamika & Imidacloprid & 10.20872 & MR \\
$\mathbf{9}$ & Arka Anamika & Cow's milk & 9.717222 & MR \\
$\mathbf{1 0}$ & Arka Anamika & Control & 19.6125 & MS \\
$\mathbf{1 1}$ & NOH-15 & Jholmal & 14.25958 & MR \\
$\mathbf{1 2}$ & NOH-15 & Azadirachtin & 10.3705 & MR \\
$\mathbf{1 3}$ & NOH-15 & Imidacloprid & 8.479722 & R \\
$\mathbf{1 4}$ & NOH-15 & Cow's milk & 13.67639 & MR \\
$\mathbf{1 5}$ & NOH-15 & Control & 21.07389 & MS \\
$\mathbf{1 6}$ & Super Green & Jholmal & 8.993056 & $\mathrm{R}$ \\
$\mathbf{1 7}$ & Super Green & Azadirachtin & 11.88289 & MR \\
$\mathbf{1 8}$ & Super Green & Imidacloprid & 6.805361 & $\mathrm{R}$ \\
$\mathbf{1 9}$ & Super Green & Cow's milk & 9.155 & $\mathrm{R}$ \\
$\mathbf{2 0}$ & Super Green & Control & 19.46083 & MR \\
$\mathbf{2 1}$ & Julie & Jholmal & 9.57675 & MR \\
$\mathbf{2 2}$ & Julie & Azadirachtin & 12.96303 & MR \\
$\mathbf{2 3}$ & Julie & Imidacloprid & 6.898083 & R \\
$\mathbf{2 4}$ & Julie & Cow's milk & 11.19583 & MR \\
$\mathbf{2 5}$ & Julie & Control & 18.81417 & MR \\
\hline $\mathbf{2}$ & & & & \\
\hline
\end{tabular}

Where,

$\mathrm{R}=$ Resistant

$\mathrm{MR}=$ Moderately Resistant

$\mathrm{MS}=$ Moderately Susceptible

Above table shows that Super Green -Jholmal, Super Green Imidacloprid, Super Green Cow's Milk, Julie Imidacloprid and NOH-15 Imidacloprid are the highly resistant among all the varieties with management practices. Since, the variety Super Green is a hybrid variety; it may be showing the good performance in terms of many traits including the disease response.

\section{CONCLUSION}

From results and fore going discussion it may be concluded that Julie variety can be the promising variety; that not only showed the lowest disease incidence but also have relatively lower yield reduction against okra yellow vein mosaic virus compared to other variety. In case of management option, Azadiractin was found to be effective for controlling disease which was at par 
with Imidacloprid. Three foliar spray of Azadiractin (@ 5ml/L) or Imidacloprid (@2ml/L) at interval of 15 days may be the option for the management of OYVMV. However, Imidacloprid has the long waiting period and is harmful for beneficial organisms, plants and human health. So, Azadiractin can be alternative method for farmer for management of OYVMV.

\section{ACKNOWLEDGEMENT}

It is our great pleasure to acknowledge the contributions made by various persons and institutions in research work and preparation of this manuscript. We would like to express our deep sense of gratitude to Assistant Prof. Subodh Khanal, for his continuous advice, support and for never tiring of answering our questions during the entire study period. We would like to express thanks to Institute of Agriculture and Animal Science (IAAS), Paklihawa for providing financial support and experiment materials for the research. We wish to extend our special thank to National Wheat Research Program, Bhairahawa for providing research materials. Likewise, special thank to Regional Agriculture Research Station (RARS), Tarahara, Sunsari for providing seeds for our research.

\section{REFERENCES CITED}

Ali, M. I., Khan, M., Rashid, A., \& Sajid, M. (2012). Epidemiology of Okra Yellow Vein Mosaic (OYVMV) and Its Management through Tracer, Mycotol and Imidacloprid. American Journal of Plant Sciences, 3, 1741-1745.

Ali, S., Khan, M. A., Habib, A., Rasheed, S., \& Iftikhar, Y. (2005). Management of Yellow vein mosaic disease of okra through pesticides/bio-pesticide and suitable cultivars. International journal of agriculture and biology.

Capoor, S. P., \& Verma, P. M. (1950). Yellow vein mosaic of Hibiscus esculentus L. Indian Journal of Agricultural Science, 20, 217 - 230.

Chaudhary, A., Khan, M., \& Bilal, Y. (2016). Management of Okra Yellow Vein Mosaic Virus and its Vector through Plant Extracts. Journal of Plant Pathology \& Microbiology, 8, 1-3.

Khushk, A. M., Usman, S. M., \& Memon, M. A. (2003). The cultivation of okra in Sindh and its economic view, PARC Technology transfer institute, Tandojam. Sindh Zarat, 136, 17-18.

Oliveria, M., Henneberry, T., \& Anderson, P. (2001). History, current status and collaborative research projects for Bemesia tabaci. In Crop Protection, 20, 709-723.

Osekita, B. A. (2009). Correlation and Path Coefficient Analyses of Seed Yield Attributes in Okra (Abelmoschus esculentus L.Moench. African Journal of Biotechnology, 1330-1336.

Rashid, M. M. (1999). Shabji Biggan (in Bengal). Dhaka: Bangla Academy.

Sastry, K. M., \& Singh, S. J. (1975). Yellow mosaic of Bhindi. Curr. Sci, 9, 227-228.

Sharma, R., Gupta, V., Jindal, J., \& Dilawari, V. (2008). Host associated genetic variations in whitefly, Bemesia tabaci (Genn.). Indian Journal of Biotechnology, 7, 366-370. 